\title{
ANALISIS KUALITAS PELAYANAN DALAM PENERBITAN SERTIFIKAT TANAH DI BADAN PERTANAHAN NASIONAL KABUPATEN NAGAN RAYA
}

\author{
Ikhwal Mauliza $^{1}$, Fadhil Ilhamsyah ${ }^{2}$, Hasanuddin $^{3}$ \\ ${ }^{1}$ Fakultas Ilmu Sosial dan Ilmu Politik, Universitas Teuku Umar, Indonesia \\ ${ }^{2}$ Dosen Ilmu Administrasi Negara, Universitas Teuku Umar, Indonesia \\ ${ }^{3}$ Badan Pertahanan Nasional Kabupaten Nagan Raya, Indonesia \\ Email: ikhwalmauliza26@gmail.com, fadhil.ilhamsyah@utu.ac.id, \\ hnuddin980@gmail.com
}

\section{Abstract}

The purpose of this study is to analyze the quality of service in the issuance of land certificates at Badan Pertanahan Nasional (BPN) Nagan Raya Regency. This research is qualitative research with a post-positivist approach. In this study the data obtained by researchers from observations, interviews, and documentation. The results of this study note that the certainty of the time and method of service in the issuance of land certificates at the BPN Nagan Raya Regency is still not done well. This is because officers still often extend the process of making land certificates, then in terms of the cost of obtaining land title certificates at the Nagan Raya BPN office, there are still many people who feel dissatisfied because there are additional costs that must be met by the community such as transportation costs for officers. Then regarding the obstacles that are often encountered by officers in terms of issuing land certificates are the frequent occurrence of disputes or disputes over land, incomplete files in the management of land certificates, boundary stakes, and lack of timeliness. Therefore, it is expected that employees at the Nagan Raya Regency BPN Office can provide accurate explanations to the community when processing land certificates both in terms of completeness of files, costs and time required by employees, so that with this the community can feel good service and comfort. and employees can carry out their duties according to the tempo that has been given to the community.

Keywords: quality; service; land certificate issuance

\section{Abstrak}

Tujuan dari penelitian ini adalah untuk menganalisis kualitas pelayanan dalam penerbitan sertifikat tanah di Badan Pertanahan Nasional (BPN) Kabupaten Nagan Raya. Penelitian ini merupakan penelitian kualitatif dengan pendekatan post-positivis. Dalam penelitian ini data yang diperoleh oleh peneliti dari hasil observasi, wawancara, dan dokumentasi. Hasil penelitian ini diketahui bahwa kepastian waktu dan cara pelayanan dalam penerbitan sertifikat tanah di BPN Kabupaten Nagan Raya masih belum dilakukan dengan baik. Hal ini 
dikarenakan petugas masih sering memperpanjang waktu proses pembuatan sertifikat tanah, kemudian dalam hal biaya pengurusan sertifikat hak milik atas tanah di kantor BPN Nagan Raya masih banyak banyak masyarakat yang merasa tidak puas karena adanya biaya tambahan yang harus dipenuhi oleh masyarakat seperti biaya transportasi petugas. Kemudian mengenai hambatan yang sering dijumpai oleh petugas dalam hal penerbitan sertifikat tanah adalah sering terjadinya sengketa atau perselisihan atas tanah, ketidak-lengkapannya berkas dalam pengurusan sertifikat tanah, batas patok , dan kurangnya ketepatan waktu. Oleh sebab itu diharapkan kepada pegawai di Kantor BPN Kabupaten Nagan Raya agar dapat memberikan penjelasan yang akurat kepada masyarakat saat pengurusan sertifikat tanah baik dalam hal kelengkapan berkas, biaya serta waktu yang diperlukan oleh pegawai, sehingga dengan hal ini masyarakat dapat merasakan pelayanan yang baik serta kenyamanan dan pegawai dapat mengerjakan tugasnya sesuai dengan tempo yang telah diberikan kepada masyarakat.

Kata kunci: kualitas; pelayanan; penerbitan sertifikat tanah

Diterima: 23-10-2021

Direvisi: $15-11-2021$

Diterbitkan: 20-11-2021

\section{Pendahuluan}

Kabupaten Nagan raya memiliki luas wilayah yang relatif kecil dibandingkan dengan Kabupaten/kota lainnya, namun memiliki jumlah penduduk yang relatif besar yang sama dengan kota-kota besar lainnya. Kabupaten Nagan Raya memiliki luas wilayah $3.545 \mathrm{~km}^{2}$ dengan jumlah penduduk sekitar 93.392 jiwa. Dari jumlah penduduk tersebut tercatat hanya $70 \%$ yang memiliki sertifikat kepemilikan. Hal ini disebabkan oleh kondisi birokrasi yang dimiliki masih terbilang rumit dan lamban sehingga mengakibatkan masyarakat menjadi malas dalam hal pengurusan sertifikat tanah dan juga disebabkan karena pemikiran masyarakat yang merasa bahwa tidak terlalu pentingnya sertifikat tanah tersebut. Masyarakat berpikir hanya dengan adanya akta jual beli, saksi-saksi dan surat keputusan pemberian hak atas tanah itu dapat dijadikan sebagai bukti yang kuat bahwa tanah tersebut adalah milik mereka, kecuali masyarakat yang ingin melakukan pinjaman ke bank maka masyarakat akan mulai mengurus sertifikat tersebut agar dapat dijadikan sebagai jaminan kepada pihak bank. Dan terdapat banyaknya masyarakat yang tidak mengurus sertifikat tanahnya sendiri diakibatkan karena masyarakat berpikir bahwa pengurusannya yang sangat berbelit-belit serta membutuhkan jangka waktu yang relatif lama. Maka masyarakat lebih memilih menggunakan jasa notaris agar sertifikat tanah mereka cepat selesai, padahal jika masyarakatnya mengurus sendiri sertifikat tanah tersebut akan lebih murah karena masyarakat tidak dikenakan biaya jasa notaris.

Hal terpenting dalam penyelenggaraan pelayanan publik yaitu adanya kesadaran yang tinggi dari para aparat pemerintahan bahwa mereka merupakan tenaga pengabdi masyarakat yang memberikan pelayanan publik kepada masyarakat dan dengan demikian wajib memberikan pelayanan terbaiknya. Badan Pertanahan Nasional Kabupaten Nagan Raya merupakan unsur pelaksana pemerintah Kabupaten Nagan Raya 
di bidang pertanahan, yang dipimpin oleh seorang petugas kantor yang melapor dan bertanggung jawab kepada kepala bidang melalui sekretaris kepala bidang yang menyelenggarakan beberapa urusan anggaran di bidang pertanahan dan akibatnya memimpin bidang tugas penerbitan sertifikat hak atas milik tanah yang menunjukan bahwa masalah kualitas pelayanan, seperti profesional, biaya transportasi, ketepatan waktu dan partisipasi yang ditargetkan oleh masalah tersebut tidak diselesaikan secara optimal.

Dalam memberikan kualitas pelayanan pertanahan yang berasas keadilan adalah menjadi tuntutan masyarakat saat ini menurut (Hermawan et al. 2016). Sebagai anggota masyarakat semua individu membutuhkan pelayanan dari pihak lain. Pelayanan publik merupakan layanan yang dilakukan terhadap masyarakat dengan tujuan untuk lebih memuaskan masyarakat dalam mengurusi berbagai kepentingan (Pasolong 2010). Fungsi-fungsi sosial perlu diwujudkan oleh pemerintah dalam menyelenggarakan pelayanan publik guna memenuhi kebutuhan setiap masyarakat serta membuat kesejahteraan masyarakat menjadi meningkat.

Namun faktanya masih banyak kendala dalam pelayanan publik yang dirasakan oleh masyarakat secara langsung. Masyarakat masih merasa pelayanan publik kurang memuaskan. Hal ini ditandai dengan masih banyaknya keluhan dari masyarakat yang disampaikan melalui berbagai media sehingga dapat menimbulkan citra buruk terhadap pelayanan publik yang dilakukan oleh pemerintah. Semua anggota masyarakat mempunyai hak atas pelayanan publik yang disediakan oleh pemerintah melalui aparataparatnya namun pada faktanya tidak sedikit masyarakat yang merasa bahwa pelayanan yang diberikan oleh pemerintah masih belum sesuai dengan harapan. Salah satu hal yang dirasa kurang pelayanannya adalah terkait penerbitan sertifikat kepemilikan tanah.

Hal tersebut tidak sesuai dengan Undang-Undang Nomor 32 Tahun 2004 tentang pemerintahan daerah yang menyatakan bahwa aparat Negara wajib memberikan pelayanan terbaik dan bertujuan untuk dapat memenuhi kebutuhan dan juga kepuasan publik guna meningkatkan pelayanan yang diberikan kepada masyarakat. Contoh jenis pelayanan tersebut adalah pelayanan administrasi, pelayanan barang dan jasa. Dalam pelayanan administrasi, terdapat layanan penerbitan sertifikat tanah untuk melindungi kepemilikan tanah masyarakat.

Pelayanan yang paling banyak diburu oleh masyarakat adalah pelayanan sertifikat tanah. Hal tersebut disebabkan karena saat ini masyarakat telah menyadari akan betapa pentingnya kelengkapan pengadministrasian tanah. Tanah memiliki nilai aset yang tinggi sehingga membuat masyarakat membeli tanah untuk investasi kedepannya (Harahap 2017). Sertifikat tanah merupakan sebuah alat bukti baik yang termuat di dalamnya baik itu data fisik maupun data yuridis, dimana data tersebut sesuai dengan yang ada di surat tanah yang bersangkutan yang diterbitkan oleh Kantor Pertanahan (Fitriya and Hadilinatih 2018). Sertifikat tanah menurut UndangUndang Pokok Agraria sangat penting guna mewujudkan jaminan kepastian hukum dan kepastian hak atas tanah. Sertifikat juga mempunyai fungsi sebagaimana diatur dalam Pasal 32 PP 24 Tahun 1997: sertifikat merupakan alat bukti hak dan berlaku 
untuk alat bukti yang kuat atas data fisik dan data hukum yang terkandung di dalamnya".

Berdasarkan hasil survey penelitian diketahui bahwa permintaan akan tanah dan perumahan akan menimbulkan berbagai konflik dan perselisihan antara individu dan kelompok terkait. Perselisihan tersebut dapat berupa sengketa waris, sengketa kepemilikan, dan sengketa pemilikan tanah dan rumah tanpa hak. Bahkan pengusiran konstruksi ilegal di tanah negara atau individu adalah konflik yang semakin umum saat ini.

Guna meminimalisir hal tersebut, maka dibutuhkanlah sebuah kepastian hukum yang berwujud sertifikat tanah. Hal tersebut digunakan untuk menjamin terkait kepastian hukum. Pemerintah telah menghimbau masyarakat untuk membuat sertifikat tanah yang sah guna meminimalisir hal-hal yang tidak diinginkan. Untuk memastikan bahwa pembangunan gedung sudah sesuai dengan peraturan teknis dan juga peraturan hukum, maka setiap pembangunan yang dilaksanakan harus sesuai dengan persyaratan teknis dan manajemen yang terkait dan komprehensif. Rumusan persyaratan manajemen konstruksi membantu pelamar atau pendaftar untuk memahami lebih detail persyaratan yang diperlukan untuk konstruksi, termasuk kejelasan status tanah, kejelasan status kepemilikan bangunan, dan kepastian hukum. Bangunan tersebut telah disetujui oleh pemerintah dalam bentuk izin mendirikan bangunan.

Pemerintah telah melakukan himbauan bagi masyarakat yang memiliki tanah dan atau bangunan untuk memiliki sertifikat kepemilikan yang sah, namun masyarakat berasumsi bahwa dalam mengurus sertifikat tanah membutuhkan kesabaran lebih karena merepotkan dan prosesnya harus rumit sehingga masyarakat merasa enggan dan malas. Sebagian besar masyarakat masih belum memperdulikan sertifikat tanahnya, karena dianggap akan lebih merepotkan untuk mengurusnya, dan membutuhkan waktu yang lama, sehingga semua orang akan mengurusnya melalui jasa notaris, sehingga sertifikat tanah tersebut dapat diurus dan diproses dengan cepat.

Banyak penelitian terdahulu yang sudah melakukan penelitian tentang kualitas pelayanan dalam pengurusan sertifikat tanah, hal ini dapat dilihat dari penelitian yang dilakukan oleh Bernardianto dan Fitriyah (2018) dengan judul "Kualitas Pelayanan Pembuatan Sertifikat Tanah Pada Kantor Pertanahan / Badan Pertanahan Nasional Kota Palangka Raya". Penelitian ini menggunakan metode kualitatif. Menurut penelitian ini bahwa Kantor Pertanahan/Badan Pertanahan Nasional Kota Palangka Raya telah melayani masyarakat dengan sangat baik namun tentu saja ada sebagian masyarakat yang merasa tidak puas terhadap pelayanan yang telah diberikan. Ada lima dimensi atau aspek untuk mengukur kualitas pelayanan penerbitan sertifikat tanah yaitu: tangible, reliability, responsiveness, assurance dan empathy. Adapun saran kedepannya adalah agar Kantor Pertanahan/Badan Pertanahan Nasional Kota Palangka Raya dapat memberikan pelayanan yang lebih berkualitas agar masyarakat dapat mengurus sertifikat tanahnya dengan lebih cepat dan memberikan prioritas pada peningkatan mutu 
layanan serta ketepatan waktu untuk pengurusan surat sertifikat tanah menurut SOP yang berlaku (Biroum and Fitriyah 2018).

Kemudian penelitian yang dilakukan oleh Sapioper, Plassy dan Ilham (2021) dengan judul Kualitas Pelayanan Sertifikat Tanah Hak Milik Di Kantor Pertanahan Kabupaten Jayapura, metode yang dilakukan dalam penelitian ini adalah menggunakan metode kualitatif. Menurut hasil penelitian yang dilakukan bahwa kantor ini telah memberikan pelayanan yang terbaik dengan mengikuti prosedur pelaksanaan sesuai standar pelayanan yang ditetapkan. Namun, dari aspek ketersediaan sarana dan prasarana di kantor ini masih belum memenuhi standar pelayanan yang berlaku. Disamping itu, terdapat kendala lain yaitu minimnya pelayanan berdasarkan ketepatan waktu penyelesaian pengaduan yang diterima dari masyarakat sehingga hal itu dirasakan masih kurang memuaskan untuk pengguna layanan (Sapioper et al. 2021).

Hal ini menunjukkan belum optimalnya kualitas pelayanan publik seperti waktu, efektivitas biaya, transparansi, kapasitas dan partisipasi tercermin dalam kendalakendala tersebut. Kendala-kendala tersebut juga dihadapi oleh BPN Naga Raya yang terletak di Kabupaten Nagaraya. Berdasarkan hasil observasi selama magang diketahui bahwa masyarakat yang mengurus sertifikat tanah di BPN Naga Raya dapat dihitung oleh jari yaitu rata-rata per hari hanya 5 orang. Berdasarkan latar belakang diatas maka penulis tertarik untuk mengadakan penelitian terkait analisis kualitas pelayanan dalam penerbitan sertifikat tanah di BPN kabupaten Nagan Raya dimana penelitian ini diharapkan dapat menjadi evaluasi untuk pelayanan pembuatan sertifikat hak tanah di BPN kabupaten Nagan Raya kedepannya. Oleh sebab itu peneliti tertarik untuk melakukan penelitian dengan judul "Analisis Kualitas Pelayanan dalam Penerbitan Sertifikat Tanah di Badan Pertanahan Nasional Kabupaten Nagan Raya”.

\section{Metode Penelitian}

Penelitian ini dilakukan di Kantor Badan Pertanahan Nasional Kabupaten Nagan Raya. Metode yang peneliti lakukan dalam penelitian ini bersifat kualitatif yang dilakukan pada kondisi yang alamiah yaitu penelitian yang berdasarkan data deskriptif baik itu berupa tulisan maupun lisan orang-orang. Penelitian kualitatif adalah suatu proses penelitian yang memberikan pemahaman berdasarkan metodologi yang bersifat menyelidiki suatu fenomena sosial yang ada dalam masyarakat.

Sehubungan dengan penelitian ini, metode yang digunakan adalah pendekatan post-positivis. Menurut Creswell (2018), pendekatan post-positivis adalah metode yang menyimpang dari teori, kemudian peneliti melakukan kegiatan pengumpulan data untuk mendukung/membantah teori tersebut, dan memperbaiki hasil penelitian berdasarkan hasil penelitian.

Pada penelitian ini jumlah informan yang digunakan sebanyak 4 orang informan yaitu 1 orang Kepala BPN Munir SE, 1 orang Pegawai BPN Farhad Lubis SH pelayanan dan 2 orang Masyarakat yang mengurus sertifikat tanah.Untuk memperoleh data yang diperlukan dalam penelitian ini, pengumpulan data dilakukan melalui observasi,wawancara, dan dokumentasi. Waktu yang digunakan peneliti dalam 
melakukan penelitian dilaksanakan sejak proses pemagangan selama 6 bulan di Kantor Pertanahan Nasional Kabupaten Nagan Raya.

Observasi atau pengamatan adalah kegiatan sehari-hari manusia dengan panca indera mata sebagai alat utama, (langsung masuk ke tempat kejadian untuk melihat dengan mata kepala sendiri).

Wawancara adalah: percakapan dengan tujuan tertentu. Suatu percakapan tersebut dilakukan oleh dua pihak, yaitu pewawancara yang mengajukan pertanyaan dan terwawancara yang menjawab pertanyaan.

Dokumentasi: rekaman penting melakukan penelitian untuk memecahkan masalah yang terjadi pada objek penelitian, pengalaman peneliti, dan keyakinan masyarakat, fungsinya adalah sebagai mendukung dan melengkapi data asli yang diperoleh melalui observasi dan wawancara. Materi dokumen yang dilakukan seperti foto, otobiografi, surat pribadi, buku harian, peringatan, kliping koran, dokumen pemerintah dan swasta, roman/cerita rakyat, kaset, mikrofilm, compact disc, compact disc, data server/flash drive, data yang disimpan di situs web.

Teknik pengolahan data yang digunakan penulis dalam penelitian ini menjadi hal utama yang harus dipilih. Memusatkan perhatian pada hal-hal yang penting, mengabstraksikan data, dan mengorganisasikan data yang dikumpulkan dari catatan lapangan, observasi, dan catatan tertulis. Kemudian peneliti dapat merekamnya dan mengubah data utama dan penting untuk diolah menjadi data yang lebih mudah dipahami, karena data yang diperoleh tidak tersusun dengan rapi. Kemudian peneliti mengorganisasikan data tersebut agar lebih mudah dipahami oleh pembaca. Teknologi analisis data adalah proses menemukan solusi dalam bentuk yang lebih mudah dipahami. Setelah mengumpulkan data, hubungkan dengan teori yang ada. Data terkait Kualitas Pelayanan dalam Penerbitan Sertifikat Tanah di Badan Pertanahan Nasional Kabupaten Nagan Raya. Kemudian disusun berdasarkan urutan pembahasan yang telah direncanakan. Proses analisis data dilakukan dengan cara menganalisis data-data yang telah diperoleh melalui teknik pengumpulan data yang telah ditetapkan kemudian dideskripsikan. Analisis data yang dilakukan dengan menggunakan teknik deskriptif komparatif kemudian dianalisis dengan menggunakan reduksi data, penyajian data dan penarikan kesimpulan.

\section{Hasil dan Pembahasan \\ Persyaratan Pelayanan}

Berdasarkan hasil wawancara terhadap informan diperoleh hasil bahwa dalam pengurusan sertifikat tanah persyaratan administrasi yang harus dipenuhi adalah KTP, $\mathrm{KK}$, PBB tahun berjalan, membawa formulir dari BPN dan map warna kuning, dan fotocopy surat tanah dari awal sampai akhir. Ketentuan-ketentuan tersebut wajib untuk dibawa guna memudahkan proses administrasi. Informan juga menuturkan bahwa persyaratan tersebut sudah sesuai kebutuhan dalam pemenuhan data pengurusan sertifikat tanah. Persyaratan-persyaratan tersebut sesuai dengan pelayanan pertanahan yang diatur dalam Peraturan Kepala Badan Pertanahan Nasional Nomor 1 Tahun 2010 
tentang standar pelayanan dan pengaturan pertanahan yaitu: 1) Permohonan bermaterai lengkap dan ditandatangani oleh pemohon atau wakilnya. 2) Surat kuasa. 3) Konfirmasi identitas pemohon dan wakil resminya (KTP, KK) dan aslinya Harus diterbitkan oleh petugas loket. 4) Sertifikat pengadaan tanah asli/kepemilikan tanah.

Persyaratan administrasi yang diterapkan di kantor Pertanahan Nasional Nagan raya sudah sesuai dengan UU, akan tetapi masih terdapat beberapa permasalahan dalam pengurusan sertifikat tanah diantaranya kelengkapan berkas atau data yang diberikan oleh masyarakat, hal ini terjadi disebabkan karena masih kurangnya para pegawai BPN Nagan Raya melakukan sosialisasi mengenai persyaratan administrasi sertifikat hak milik atas tanah. Hal tersebut bertolak belakang dengan hasil penelitian Putri Vara Dina (2016) dimana hasil penelitian menunjukkan bahwa selama proses pengurusan sertifikat tanah dapat dilihat kurang efektifnya pelayanan yang diberikan oleh petugas BPN. Hal tersebut diakui pula oleh petugas pelayanan bahwa kendalanya adalah kekurangan jumlah petugas yang tersedia untuk memberikan layanan pengurusan sertifikat dibandingkan dengan masyarakat yang meminta pelayanan tersebut. Maka dari itu diperlukan penambahan petugas agar pelayanan yang diberikan dapat memenuhi pelayanan berkualitas seperti diharapkan oleh masyarakat.

\section{Prosedur Pelayanan Dalam Pembuatan Sertifikat Tanah Di Kantor Pertanahan Nasional Nagan Raya}

Berdasarkan hasil wawancara dengan informan diketahui bahwa tata cara prosedur pelayanan penerbitan sertifikat hak milik di Badan Pertanahan Nasional Nagan Raya harus memenuhi kelengkapan seperti KK, KTP, PBB tahun berjalan, formulir data dan fotocopy seluruh surat hak atas milik tanah dari awal sampai akhir serta di sertifikasi oleh notaris atau perwakilan resmi. Setelah semua persyaratan lengkap dinyatakan oleh petugas loket, maka petugas loket akan mencetak SPS (surat perintah sektor) kemudian akan keluar berapa biaya dari pengukuran (biaya tergantung luas pengukuran tanah), berapa luas tanahnya serta lokasi tanah tersebut berada. Setelah membayar petugas loket pemohon kemudian membawa bukti SPS tersebut ke bank kemudian akan dikirim ke bendahara, bendahara mengirimkan ke bagian survey, setelah itu surveyor melakukan koordinasi dengan pemohon kapan pengurusan pengukuran tanah dapat dilaksanakan, kemudian akan dikeluarkannya produk yang namanya peta bidang. Petugas ukur tidak dapat membantu pemohon untuk menunjukkan batas patok tanah. Hasilnya adalah perwerek ke meteran setelah pemohon tanda tangan dan kemudian diproses (koordinat) TM3, satelit, gambar, pengukuran dan pemetaan. Kemudian ditandatangani oleh kepala seksi hak dan pendaftaran tanah dan dikirim ke administrator untuk pengambilan nomor. Setelah mendapatkan nomor tersebut pemohon dapat mengambil peta bidang lapangan dengan catatan membawa kwitansi asli.

Berdasarkan hasil tersebut dapat disimpulkan bahwa prosedur pelayanan di kantor BPN Nagan Raya dalam pengurusan sertifikat tanah tidak terdapat persyaratan yang berbelit-belit dan dapat dengan mudah dilengkapi oleh masyarakat. Pernyataan tersebut juga didukung oleh hasil wawancara terhadap informan lain. Prosedur layanan 
yang berlaku di BPN Kabupaten Nagan Raya dalam pengurusan sertifikat tanah sudah sesuai dengan prosedur yang ditetapkan oleh pemerintah (Santoso 2007). Adapun mekanisme pelayanan dalam penerbitan sertifikat tanah: 1) Masyarakat menyerahkan semua berkas persyaratan mereka dan petugas memeriksa di loket layanan. 2) Masyarakat yang bersangkutan kemudian membayar untuk pengukuran dan pemeriksaan tanah. 3) Proses selanjutnya adalah mengukur dan memeriksa tanah, dimana pemohon harus hadir. 4) Selanjutnya diterbitkan Surat Keputusan Kantor Pertanahan, Surat Keputusan Dinas Pertanahan dan Surat Keputusan Badan Pertanahan Nasional Republik Indonesia, dan selesailah penghitungan hak dan penerbitan sertifikat tersebut.

Dengan menggunakan proses pelayanan yang diuraikan diatas, terlihat jelas bahwa bagaimana proses penerbitan sertifikat tanah itu sendiri mulai dari pemenuhan dokumen hingga penerbitan sertifikat tanah. Namun pada kenyataannya banyak masyarakat yang menjadi pemohon dalam pengurusan sertifikat tanah masih kurangnya memahami sepenuhnya persyaratan-persyaratan yang harus dilengkapi sehingga hal ini dapat mengakibatkan keterlambatan dalam pembuatan sertifikat hak atas milik tanah. Maka dapat disimpulkan bahwa prosedur pelayanan dalam pembuatan sertifikat hak milik atas tanah belum berjalan secara maksimal. Hal tersebut sejalan dengan penelitian yang pernah dilakukan oleh Tanjungsari (2007) dimana terkait pelayanan di Kantor Pertanahan Kabupaten Banyuwangi masih terkendala oleh masyarakat yang kurang mengerti tentang prosedur pengurusan sertifikat hak tanah. Hal tersebut sesuai dengan hasil penelitian Widuri dan Maesaroh (2016).

\section{Waktu Pelayanan Penerbitan Sertifikat Tanah Di BPN Nagan Raya}

Salah satu narasumber yang merupakan Kepala Sub Bagian Tata Usaha di kantor BPN Nagan Raya menuturkan bahwa penerbitan sertifikat hak milik atas tanah diproses selama 60 hari dengan ketentuan masyarakat sudah melengkapi persyaratannya. Selain itu, berdasarkan hasil observasi diketahui bahwa selama ini terdapat ketidak-tepatan waktu dalam penerbitan sertifikat hak milik atas tanah oleh BPN Kabupaten Nagan Raya. Hal ini disebabkan karena dokumen-dokumen yang dimiliki masyarakat tidak lengkap. Sehingga dapat disimpulkan yang menjadi hambatan dalam proses pembuatan sertifikat tanah adalah kelengkapan berkas dari masyarakat. Kesimpulan tersebut sesuai dengan hasil penelitian Abidin dkk., (2019) yang membahas terkait faktor-faktor yang mempengaruhi kualitas pelayanan pembuatan sertifikat tanah diantaranya adalah kurangnya kesadaran masyarakat.

\section{Biaya Dalam Pembuatan Sertifikat Tanah Di Kantor Pertanahan Nagan Raya}

Biaya dalam pembuatan sertifikat hak milik tanah di BPN Kabupaten Nagan Raya sudah dengan PP No. 128 Tahun 2015 Pasal 4, mengenai Tarif pelayanan pengukuran dan pemetaan batas bidang tanah yaitu dihitung berdasarkan rumus: 
Gambar 1. Tarif biaya pelayanan pemeriksaan tanah

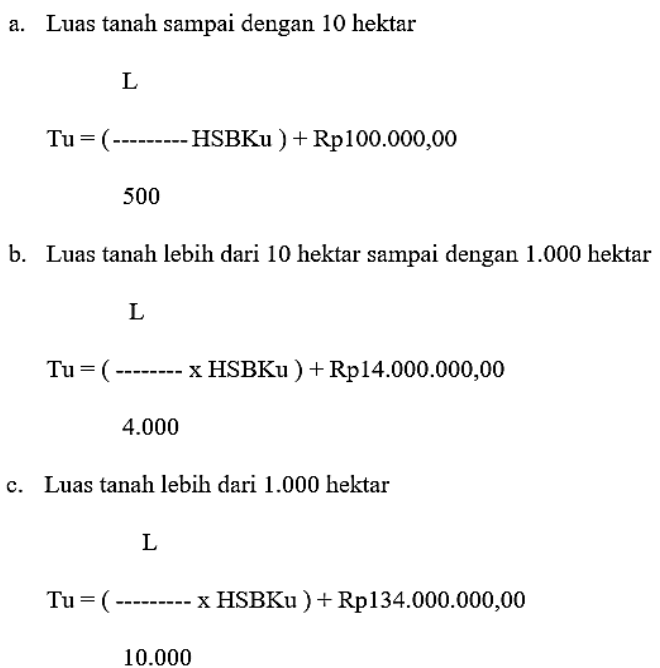

Sumber: Kantor Badan Pertanahan Nasional Nagan Raya Tahun 2015

Pasal 7 mengenai Tarif Pelayanan Pemeriksaan Tanah oleh pegawai dihitung berdasarkan rumus:

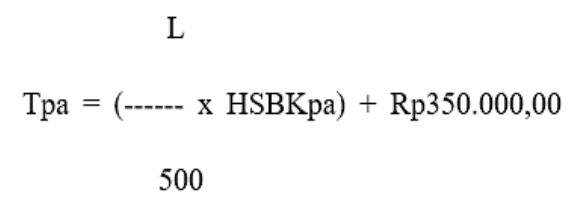

Berdasarkan hasil wawancara ditemukan adanya terjadi peningkatan biaya dalam penerbitan sertifikat hak milik atas tanah, dimana petugas membebankan biaya transportasi kepada masyarakat.

Pengenaan biaya pelayanan yang ditetapkan pada Badan Pertanahan Nasional Kabupaten Nagan Raya telah sinkron dengan menggunakan peraturan pemerintah republik indonesia no. 128 tahun 2015 tentang jenis dan tarif atas jenis peneriman negara bukan pajak yang berlaku dalam kementerian agraria dan tata ruang atau badan pertanahan nasional sebagaimana yang telah diatur dalam pasal 4 tentang tarif pelayanan pengukuran dan pemetaan batas bidang tanah dan pasal 7 tentang tarif pelayanan pemeriksaan tanah oleh panitia. Jaminan waktu pelayanan pembuatan sertifikat tanah (assurance dari hasil penelitian dilapangan diketahui bahwa ada perbedaan waktu pelayanan terhadap target waktu sebagaimana telah ditentukan menurut standar operasional pelayanan sehingga konsekuensi yang ditimbulkan adalah terjadinya penundaan penerbitan sertifikat tanah hingga bertahun-tahun. Dengan demikian dapat disimpulkan bahwa masalah tersebut timbul karena aturan tentang jangka waktu pelayanan yang tidak jelas. Hal tersebut sesuai dengan hasil penelitian Widuri dan Maesaroh (2016) dimana hasil dilapangan menunjukkan bahwa jaminan waktu pelayanan pembuatan sertifikat tanah (assurance) mengindikasikan adanya perbedaan waktu pelayanan terhadap target waktu penyelesaian seperti ditentukan oleh 
standar operasional pelayanan yang kemudian menyebabkan penerbitan sertifikat tanah menjadi tertunda hingga lebih dari setahun. Hal tersebut menunjukkan adanya masalah berkaitan dengan kurang jelasnya peraturan jangka waktu pelayanan yang harus diikuti.

Berdasarkan hasil penelitian diatas dapat disimpulkan bahwa Ada beberapa faktor yang mendukung bahwa pelayanan secara signifikan berkaitan dengan kepuasan masyarakat, antara lain: (1) masyarakat mampu menerima layanan yang telah diberikan oleh para pegawai sesuai dengan prosedur dan aturan yang ada, karena memiliki kompetensi dan kepedulian yang tinggi dalam memberikan pelayanan khususnya dalam penerbitan sertifikat tanah pada kantor Badan Pertanahan Nasional Nagan Raya sehingga harapan masyarakat melebihi dari kenyataan yang ada, (2) adanya kerja sama yang baik antara semua pegawai dalam memberikan pelayanan kepada masyarakat, sehingga urutan pelayanan sesuai waktu yang telah ditentukan dan sesuai dengan kelengkapan berkas yang dibawa oleh pengguna jasa, artinya tiap prosedur yang dilalui masyarakat jelas dan terukur, dan (3) adanya tanggung jawab yang diemban oleh masing-masing pegawai sesuai dengan SOP yang ada,sehingga ada keikhlasan masingmasing pegawai dalam memberikan pelayanan. Adanya perasaan memiliki yang diperlihatkan oleh setiap pegawai dalam bertindak dan memberikan layanan, terindikasi dari tidak adanya berkas yang terbengkalai atau tertunda untuk diproses setelah memenuhi syarat-syarat tertentu, sesuai dengan ketentuan yang berlaku secara umum. Didukung oleh hasil observasi dilapangan menunjukkan bahwa ada ketepatan waktu pelayanan yang diberikan kepada masyarakat pada setiap loket yang tersedia, meskipun diakui bahwa kekurangan sumber daya manusia pada seksi pengukuran tanah masih menjadi kendala di lapangan, dengan memperhitungkan luas wilayah kerja BPN Nagan Raya sehingga data hasil pengukuran dari para petugas tersebut, menggunakan waktu yang cukup lama, sekitar satu minggu untuk diperoleh pengguna jasa layanan penerbitan sertifikat tanah tersebut.

\section{Kendala Dalam Proses Penerbitan Sertifikat Tanah Dalam Pemberian Pelayanan Pada Badan Pertanahan Nasional Nagan Raya}

Semua struktur hukum pelayanan publik selalu menjadi kendala yang dapat mengganggu proses pelayanan itu sendiri. Selain itu,ada masalah ketepatan waktu yang telah ditetapkan, tetapi dalam kenyataannya proses penerbitan melebihi waktu yang telah ditentukan. Kendala lainnya yang sering dihadapi dalam penerbitan sertifikat hak atas milik tanah adalah sering terjadinya sengketa batas-batas kepemilikan dan juga keutuhan arsip (dokumen) yang tidak lengkap menjadi lebih lama. Sedangkan menurut beberapa pemohon dari masyarakat yang telah diwawancarai adanya hambatan yang sering didapatkan adalah di mana ketepatan waktu yang telah ditetapkan prosedur adalah 60 hari namun pada waktu proses dalam penerbitan tidak sesuai dalam prosedur yang telah ditetapkan sebelumnya. Hal tersebut sesuai dengan hasil penelitian Widuri dan Maesaroh, (2016) dimana hambatan pada dimensi reliability yang diindikasikan dari belum semua petugas bisa mengoperasikan komputer dengan baik, responsiveness terkait dengan kurang cermatnya petugas dalam memeriksa berkas pemohon, dan 
assurance diindikasikan terkait penerbitan sertifikat yang sering kali melebihi target waktu yang sudah ditentukan.

Berdasarkan kendala tersebut sebagaimana teori yang dikemukakan oleh Keller dan Kopp (1987) tentang nilai (value) dari tujuan yang akan dicapai dan harapan (expectancy) agar berhasil mencapai tujuan itu. Dari 2 (dua) komponen tersebut dikembangkan menjadi 4 (empat) faktor yaitu: (1) perhatian (attention), (2) keterkaitan (relevance), (3) kepercayaan (confidence), dan (4) kepuasan (satisfaction). Terkait dengan kualitas pelayanan dengan kepuasan, perhatian pemerintah terhadap peningkatan kualitas pelayanan yang dilakukan oleh aparat birokrasi harus menjawab tuntutan dan keinginan masyarakat sebagaimana disebutkan dalam KepMenpan No. 81 tahun 1993 tentang pedoman pelayanan umum yang berkualitas. Kualitas pelayanan yang dimaksud mencakup: (1) kesederhanaan, (2) kejelasan dan kepastian, (3) keamanan, (4) keterbukaan, (5) ekonomis, (6) keadilan yang merata, dan (7) ketepatan waktu.

Berdasarkan hasil dari peneliti dengan hasil penelitian terdahulu menunjukkan bahwa kualitas pelayanan masih sangat kurang dalam hal penerbitan sertifikat tanah baik itu yang disebabkan oleh waktu penyelesaian sertifikat tanah maupun disebabkan oleh masyarakat itu sendiri dimana prosedur yang dilakukan oleh pihak pegawai di Kantor Pertanahan sudah sesuai namun kadang kala terhambat oleh persyaratan yang harus dilengkapi oleh masyarakat itu sendiri tidak lengkap.

\section{Kesimpulan}

Kesimpulan yang penulis peroleh dalam penelitian ini adalah, Badan Pertanahan Nasional Kabupaten Nagan Raya persyaratan pengurusan sertifikat tanah yang berdasarkan SOP dalam hal waktu pada pengurusan sertifikat hak milik atas tanah yang telah sesuai dengan prosedur yang telah ditetapkan, hanya saja pada waktu pengurusan sertifikat hak atas milik tanah kurang tepat dikarenakan masyarakatnya atau selaku pemohon masih menilai adanya biaya tambahan dalam hal seperti biaya transportasi petugas. Kendala yang sering kita temui dalam hal pada penerbitan sertifikat hak milik atas tanah di Kantor BPN Kabupaten Nagan Raya adalah batas-batas yang telah dipertaruhkan, sengketa proporsional dan juga keutuhan arsip (Dokumen), dan kurangnya ketepatan waktu dalam penerbitan sertifikat tanah. Sertifikat hak atas milik tanah merupakan bukti hak sebagaimana yang sudah ditetapkan dalam pasal 19 ayat 2 huruf c UUPA tentang hak atas milik tanah. Begitu juga dari hasil penelitian ini menggunakan indikator-indikator efektivitas yang belum terlaksanakan persyaratan yang harus dipenuhi yang baik terutama mengenai kepastian waktu, serta prosedur pelayanan sesuai yang telah ditetapkan. 


\section{BIBLIOGRAFI}

Abidin, T., Mustam, M., D, L., \& Warsono, H. (2019). Kualitas Pelayanan Sertifikasi Tanah di Kantor Pertanahan Kabupaten Boyolali. E-Journal UNDIP, 34-45.

Bernardianto, R. B., \& Fitriyah, P. (2018). Kualitas Pelayanan Pembuatan Sertifikat Tanah pada Kantor Pertanahan / Badan Pertanahan Nasional Kota Palangka Raya (Service Quality for Making Land Certificates at the Land Office / National Land Agency of the City of Palangka Raya). Jurnal Ilmiah Ilmu Administrasi Negara dan Ilmu Komunikasi, 5-19. Google Scholar

Creswell, J. W. (2018). Research design : Qualitative, quantitative, and mixed methods approaches. California : SAGE Publications. Buku. Google Scholar

Fitriya, \& Hadilinatih, B. (2018). Faktor-Faktor Yang Mempengaruhi Kualitas Pelayanan Pembuatan Sertifikat Tanah Pada Kantor Badan Pertanahan Nasional Kabupaten Sumenep. Jurnal Enersia Publika, 13-28. Google Scholar

Harahap, D. (2017). Efektivitas Pelayanan Dalam Penerbitan Sertifikat Hak Milik Atas Tanah Di Badan Pertanahan Nasional Kota Medan. Universitas Sumatera Utara. Google Scholar

Hermawan, W., Budiman, D., \& Hutagaol, P. (2018). Analisis Kepuasan Masyarakat Terhadap Kualitas Pelayanan Dalam Pendaftaran Tanah Pertama Kali Pada Kantor Pertanahan Kabupaten Bogor. Jurnal Ilmu Keluarga dan Konsumen, 65-75. Google Scholar

Pasolong, H. (2010). Teori Administrasi Publik. Alfabeta, 1-10. Google Scholar

Santoso, U. (2007). Hukum Agraria Dan Hak-Hak Atas Tanah. Kencana Prenada Group . Google Scholar

Sapioper, H. C., Flassy, M., \& Ilham. (2021). Kualitas Pelayanan Sertifikat Tanah Hak Milik Di Kantor Pertanahan Kabupaten Jayapura. Jurnal Borneo Administrator, 89-110. Google Scholar

Tanjungsari, E. (2007). Analisis Kualitas Pelayanan Sertifikat Tanah Secara Konversi Sporadik Di Kantor Pertanahan Kabupaten Banyuwangi. Jakarta: Universitas negeri Jember. Google Scholar

Widuri, A., \& Maesaroh. (2016). Analisis Kualitas Pelayanan pembuatan Sertifikat Tanah Di Kantor Badan Pertanahan Nasional Kabupaten Semarang. E-Journal Undip, 89-102. Google Scholar 
First publication right:

Jurnal Syntax Fusion: Jurnal Nasional Indonesia

This article is licensed under:

(c) (i) (2) 